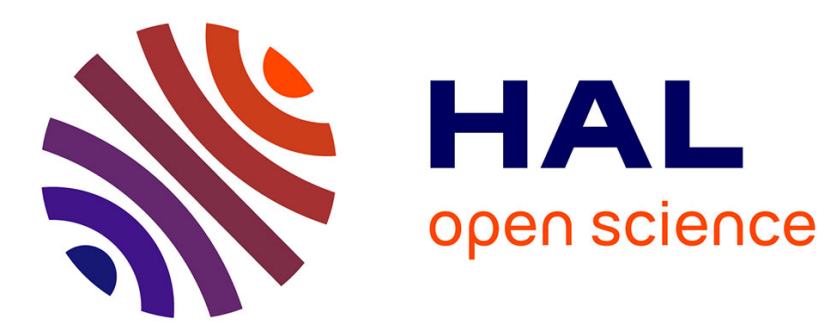

\title{
Scaling up and reverse engineering Acquisition of industrial knowledge by copying drugs in Brazil
}

\author{
Maurice Cassier, Marilena Correa
}

\section{To cite this version:}

Maurice Cassier, Marilena Correa. Scaling up and reverse engineering Acquisition of industrial knowledge by copying drugs in Brazil. The Political Economy of HIV/AIDS in Developing Countries, Edward Elgar, 2008. halshs-02024011

\section{HAL Id: halshs-02024011 https://shs.hal.science/halshs-02024011}

Submitted on 18 Feb 2019

HAL is a multi-disciplinary open access archive for the deposit and dissemination of scientific research documents, whether they are published or not. The documents may come from teaching and research institutions in France or abroad, or from public or private research centers.
L'archive ouverte pluridisciplinaire HAL, est destinée au dépôt et à la diffusion de documents scientifiques de niveau recherche, publiés ou non, émanant des établissements d'enseignement et de recherche français ou étrangers, des laboratoires publics ou privés. 


\section{Scaling up and reverse engineering}

\section{Acquisition of industrial knowledge by copying drugs in Brazil}

Maurice Cassier, CNRS, and Marilena Correa, UERJ

The Brazilian HIV/Aids programme combines the local production of ARVs by public- and private-sector pharmaceutical laboratories, with the free distribution of these drugs to patients. This was the case of first-generation ARVs, which were not under patent in Brazil before 1996, and currently applies to decisions concerning compulsory licenses on second-generation ARVs, which are patented. By mobilizing public pharmaceutical laboratories to produce these generic drugs, the Brazilian state has gone beyond its role of protecting patients and the population; it has (again) become an entrepreneur and pharmaceuticals manufacturer (Cassier and Correa, 2003). At the same time it has mobilized private laboratories producing active principles, in a perspective of industrial complementarity with public laboratories specialized in drug formulation - even if competitive situations between public and private laboratories have sometimes existed in the final drug market. Local production of ARVs and initially of AZT, launched in 1993 by the LAFEPE, a public laboratory in Recife, and Microbiologica, a private laboratory in Rio de Janeiro, has become a strategic element of both public health policy and industrial pharmaceutical policy. Local production is seen as the means to reduce the cost of ARVs for the Health Ministry (the argument was used to support calls for compulsory licences on 
Kaletra in 2005 and on Efavirenz in 2007). It was also hoped that ARV production would boost the Brazilian chemicals and pharmaceuticals industry, including its innovative capacity, but this revival has been impeded by the public procurement system which favours the importation of low-cost Chinese and Indian raw materials (Orsi et al., 2003). It is now anticipated that local production will help to improve the quality of raw materials purchased by Brazilian public laboratories which are confronted with high rates of faulty raw materials ${ }^{\mathrm{i}}$.

In the absence of technology transfer through voluntary licences granted by the international laboratories that have patented these molecules, the development of local production of active principles and anti-retroviral drugs has been based on copying and reverse-engineering by Brazilian chemists over the past fifteen years. Both chemists and economists have found this copying of ARVs, especially of certain molecules such as protease inhibitors, to be a complex task: 'Where production technologies are hard to replicate, cooperation of the patent holder might be needed to make new products available. This may be why only five of the 14 HIV/Aids anti-retrovirals were produced by a local company in India as of June 2000' (Scherer and Watal, 2001) ${ }^{\text {ii }}$. Our research focuses on these very processes of acquiring pharmaceutical knowledge through copying and reverse engineering. To fully understand this technological learning, we interviewed the chemists in charge of ARV reproduction projects at four private-sector Brazilian laboratories (Nortec, Cristalia, Labogen and 
Microbiologica) and at the Far Manguinhos federal laboratory in Rio de Janeiro. These interviews, in which the methods of the sociology of science and innovation were applied, were aimed at constructing a detailed account of the chemists' day-to-day work, their bibliographical resources, interactions with colleagues, working methods, and diverse results: molecule standards, production technologies, industrial secrets, or patent applications. A total of 55 interviews, as well as meetings at the laboratories, were recorded and transcribed in full, from December 2002 to June 2007. Reports on our observations were communicated to several of our interviewees and validated by them ${ }^{\text {iii }}$. Our results indicate that the copying of drugs is a mode of technology acquisition which offers an alternative to the technology transfer agreements or the voluntary licences generally studied in the literature (Bertin and Wyatt, 1986; Sahul, 1998). We also show that the copying of technical knowledge involves operations of translation, adaptation and reconstruction of technologies, entailing more than mere duplication, and that it produces local knowledge if not improvement innovations. In this respect our results are consistent with research on the reverse engineering economy, primarily in the electronics and computer technology sectors. As Samuelson and Scotchmer (2001) put it: 'reverse engineering is fundamentally directed to discovery and learning ... Learning what has been done before often leads to new products and advances in know how'. 
The first section of our article presents Brazil's experience in the pharmaceutical reverse engineering field since the 1980s, with a close look at Codetec's experience. We show that the creation of public and private laboratories engaged in the ARV field is largely the outcome of reverse engineering policies and practices. The second section explains the copying process, through material collected from chemists at private laboratories, primarily on API synthesizing processes, and from chemists at the federal laboratory, especially on formulations, quality control and the creation of molecule standards. The third section analyses the trading of knowledge between public laboratories, private laboratories and universities, to constitute the knowledge base needed for the local production of ARVs. In the fourth section we examine the legal battles concerning compulsory licences, from the early 2000s up to the compulsory licence decided in May 2007 for importing efavirenz and then producing it in Brazil. The conclusion considers the lessons learned from these experiences for pharmaceutical industrial policies, with a view to creating local production capacities.

\section{1- Laboratories historically founded on reverse engineering}

The Brazilian pharmaceutical laboratories currently engaged in the production of ARVs have all benefited from public incentives for reverse engineering of drugs, set up by the Health Ministry and the CEME (the government drug 
agency $^{\text {iv }}$ in the early 1980s. These laboratories are spin-off from teams at hospitals (Cristalia), universities (Microbiologica and Labogen) and the Oswaldo Cruz Foundation (Nortec) ${ }^{\mathrm{v}}$. They received generous state grants to undertake reverse engineering on what were deemed to be essential drugs. They sometimes relied on the services of Codetec, a Brazilian company created in the early 1980 s and specialized in the reverse engineering of pharmaceutical syntheses for about a decade. Codetec's trained chemists were then recruited directly by these laboratories (Labogen, Far Manguinhos).

At all the laboratories studied, whether public or private, our interviewees mentioned the crucial role and technological heritage of Codetec which had been active in the 1980s and early 1990s: 'At the time Codetec was created in Campinas. That was a very important institution because it represented the formalization of a political decision to have pharmaceutical technology of the reverse engineering type established in Brazil' (founder of the company Microbiologica). Codetec was a technology service company specialized in the reverse engineering of pharmaceutical processes. It provided custom-made industrial processes to pharmaceutical laboratories. Codetec's activity stemmed directly from the policy of the Health Ministry and CEME, designed to supply Brazil with essential drugs. The firm was set up close to the Campinas University campus. It received technological advice from several universities and recruited young graduates in chemical engineering: 'And we had a number of people consulting from Unicamp ... There was always an interaction with the 
academic world' (former scientific director at Codetec) ${ }^{\mathrm{vi}}$. It operated through tripartite contracts between itself, the CEME or the Ministry of Industry, and its client pharmaceutical firms. Any firm that wished to develop a technology turned to Codetec, which received research grants from the CEME and the Ministry of Industry. Codetec's reverse engineering methodology was highly sophisticated in respect of technological research and cost control. Projects were structured in five stages: the first stage consisted in doing bibliographical research on the molecule that was to be developed: 'Phase number one was the paperwork. What's in the literature? What is it going to cost to make this drug?' (former scientific director at Codetec). The second stage took place at the laboratory; the firm bought raw materials to analyse reactions: 'And the agreement was always that Codetec would receive all the starting materials, would not buy any starting materials. The industry would have to furnish it. (ibid)' The third stage was quality control. The fourth, the switch to the pilot scale, was decisive for developing the technology before its transfer to industry. The fifth stage was precisely that of technology transfer to the firm, systematically accompanied by an exchange of technical staff between Codetec and the client.

Codetec played the role of technology and human resource distributor in the Brazilian chemicals and pharmaceuticals industry. For instance, the Labogen laboratory set up close to the Campinas University campus, later specialized in the production of ARV active principles, recruited two experienced chemists 
from Codetec to develop its internal R\&D: '... Codetec had a very good chemist, they pulled him out. Labogen pulled out our best chemist. Because he was working with Labogen and he was able to synthesize these molecules' (Codetec scientific director). Today these two chemists manage the firm's reverse engineering projects. One of them was described to us as a virtuoso in reading patents and adapting them to local production conditions. The Codetec scientific director was recruited in the early 1990s by the Far Manguinhos federal laboratory. The reverse engineering methodology established at Far Manguinhos was fairly similar to that described for Codetec, except that for synthesis processes it stopped at the laboratory scale, whereas Codetec included the industrial pilot phase: 'and it had nine multi-purpose pilot plants ranging from $30 l$ pots to 100 or 200 litre pots'.

Microbiologica, the first private laboratory to enter the ARV copying field, was set up in the early 1980s by a team of chemists from the Federal University of Rio de Janeiro. The new company received funds from the Health Ministry to develop synthesis processes for pharmaceutical raw materials: 'The government considered the pharmaceutical industry and the making of the active principles of a strategic value. And the Ministry of Health created the programme... And it was a very easy programme to get in because the government was so interested in this programme that they offered very advantageous conditions for companies to get into these programmes of technology development' (scientific director of the company) ${ }^{\mathrm{vii}}$. The new firm was allowed to choose the molecules that it 
wanted to produce: 'So, going back to the '80s, then we started this programme on reverse technology. So, it was very easy for us because the Director of this company went to the Brazilian Ministry of Health and he was presented with a list of the so-called essential drugs. ... And I chose from the list, products which were very much within my competence, my specific academic competence' (ibid). To finance the scale-up the Health Ministry granted it a loan on advantageous terms, which it could repay with its first sales of the drug. The new company could thus recruit young PhDs from the university to develop its new products. In the early 1990s it embarked on the reverse engineering of AZT as soon as it became familiar with the molecule: 'And AZT is a nucleoside and the experience and competence of this company is in nucleic acid chemistry. So for us it's like manna from heaven' (ibid).

In the early 2000s Microbiologica ceased the production of first-generation ARVs on which Indian and Chinese competition was too strong, due to the public procurement system in Brazil. Specialized chemists trained through the reverse engineering of $\mathrm{ARVs}$ nevertheless carried on irrigating the Brazilian industry. In 2006 we met a researcher from Microbiologica at Nortec, working on improving the synthesis processes for lamivudine, and another chemist from Microbiologica had set up a new laboratory, Genvida, which from 2003-2004 developed technologies to produce second-generation ARVs under patent ${ }^{\mathrm{viii}}$.

The Cristalia laboratory, founded by a hospital doctor to produce psychotropic drugs, recruited chemists trained at the Sao Paulo and Campinas 
universities, for its R\&D laboratory. It also received funds and orders from the CEME. In 1996 Cristalia engaged in the ARV field in parallel with the creation of the Health Ministry's Aids programme. It chose to do reverse engineering on protease inhibitors, a type of ARV that was particularly difficult to copy, in order to exploit its specific competencies in organic synthesis. At the same time it worked on differentiating Indian and Chinese generics manufacturers: 'Our work is in the field of protein inhibitors whereas zidovudine and stavudine are manufactured by the Indians and Chinese; we work on more complex molecules whose synthesis is highly sophisticated' (R\&D director).

The Labogen laboratory, initially set up on the Campinas University campus and then in the immediate vicinity of the university, grew in the 1980s in direct relation with the Health Ministry's and the CEME's pharmaceutical molecule reverse engineering programme: 'The CEME helped us a lot because it funded the R\&D of the synthesis' (managing director) ${ }^{\mathrm{ix}}$. Labogen outsourced its reverse engineering projects to Codetec which was also situated close to Campinas University. It recruited Codetec researchers to reinforce its internal R\&D capacities. In the mid-1990s it engaged in the reverse engineering of AZT and of DDI and received orders from the Health Ministry.

The last laboratory to enter into the ARV field was Nortec. It did so at the request of the Far Manguinhos federal laboratory by virtue of a long-term R\&D agreement binding the private firm to the Oswaldo Cruz Foundation: 'We moved into anti-retrovirals only at the beginning of this decade 2000. And we did so at 
the request of Far Manguinhos. In terms of our agreement with Far Manguinhos, this agreement from ' 82 is still valid. We have renewed it every five years since then' (R\&D director). This private chemistry firm was a spin-off of a team of chemists at the Far Manguinhos Institute in the early 1980s, to transfer the laboratory's public research to industry: 'We were created inside Far Manguinhos. By the end of the eighties we moved here, in 1986, and we started producing in 1989 ... Our first synthetic work was performed inside Fiocruz, inside Far Manginos' (scientific director at Nortec) ${ }^{\mathrm{x}}$. The Brazilian state was also present, with a $20 \%$ share in the firm. In addition to its $R \& D$ agreement with the Far Manguinhos pharmaceutical laboratory, Nortec built long-term cooperation with chemists from the Federal University of Rio de Janeiro to help in developing new syntheses of pharmaceutical active principles.

After benefiting from public incentives for reverse engineering of essential drugs in the $1980 \mathrm{~s}$, Brazilian generics laboratories mobilized the technological know-how built up during that period, in response to the requirements and public procurement prospects of the Health Ministry's Aids programme. The generics laboratories' interactions with Brazilian universities proved to be crucial: they were hosted from the outset within the universities (Labogen); they were spawned by spin-off of academic teams (Microbiologica); they benefited from consultancy or research agreements with universities to embark on their reverse engineering projects (Nortec); and they recruited Masters' or PhD students. Relations with public pharmaceutical laboratories 
were equally strong: spin-off of chemists from Fiocruz ${ }^{\mathrm{xi}}$ (Nortec); and R\&D and technology transfer agreements (Nortec, Cristalia, Labogen). There was also a circulation of chemists between the laboratories: from Codetec to Labogen, from Microbiologica to Nortec, from Microbiologica to Genvida, from Far Manguinhos to Nortec and vice-versa. The reverse engineering projects were undertaken in-house or in cooperation (between Nortec and universities, between Labogen and Far Manguinhos, and more recently between Cristalia and Nortec).

\section{2- The copying process: reconstructing and reinventing}

The scientific director of the Far Manguinhos synthesis department summed up the copying of drugs as follows: 'it is not easy to reproduce' ${ }^{x i i}$. The Microbiologica managing director's description of reverse engineering of AZT reveals the scope of the work involved in reproducing the molecule patented by Glaxo; it was far more than just copying ${ }^{x i i i}$ : 'From the technology viewpoint it was for us a big challenge. It was not simple to make AZT at the time. It was not simple. A lot of technology had to be developed. It was not a case of reverse engineering anymore. There was a lot of innovative work being done here to produce $A Z T^{\prime}$. The Microbiologica chemists did not try to replicate the production technology in Glaxo's patent as they considered it obsolete at the beginning of the 1990s. They tried rather to invent a new synthesis route and 
produced an AZT without the impurity profile of Glaxo's AZT: 'the AZT we produced at Microbiologica in the early '90s was different in specifications to the AZT being produced by Welcome at the time. Whereas the AZT that Welcome produced had so-called "tiny impurities", ours did not. So we knew that we were making - and we knew why - we knew that we were making AZT by a different process, by a better process.' (ibid.). The copying of AZT in the early 1990s necessarily involved these changes and improvements in both process and product since the knowledge codified in the patent was several years old and the Glaxo chemists had filed their patent application in a hurry: 'Whereas, when we saw their technology, we noticed that there were a lot of weaknesses in it. And we had to develop alternative procedures to produce a better $A Z T^{\prime}$ (ibid.). The copying work was a mix of reconstruction and invention: 'For AZT we made, I think it was a combination of reverse engineering with innovative process chemistry' (ibid.).

Even though they constituted a valuable documentary base, the international patents available to the Brazilian chemists were simply a starting point in the copying process. This is mainly because the information divulged in patents is fundamentally incomplete, due to the limited descriptions of the know-how and restrictions imposed in drafting the documents. In certain cases, by contrast, the descriptions are so broad that it is literally impossible to determine the optimal conditions of the manufacturing process: "The patent is sometimes very open. In our firm, in our patents we specify: for heating, one 
uses solvents a,b,c. But we know that it's only a mixture of these agents that works, and only in certain proportions. In the patent we describe the various options. So, to do reverse engineering one has to study all types of synthesis. It's a very long process" (Director of Labogen, March 2004). Moreover, patents codify a technology whereas it is often not yet stabilized and is written hastily to ensure priority. In any case, they provide a slightly out-dated technology which does not contain the subsequent improvements made by the patent-holder. Finally, the knowledge contained in patents is not immediately transposable to local production set-ups. Chemists therefore have to translate and transpose the technology. For instance, with regard to the reproduction of Ganciclovir: 'the research staff started with the separations described in the Roche patent. They occasionally developed forms of adaptation of these processes to our factory, to local manufacturing conditions' (managing director of Labogen $)^{\text {xiv }}$. The Labogen managing director boasted about the work of a chemicals engineer who spent his time reading patents to summarize them and identify the steps that would be difficult to reproduce: 'we have someone here called Marcio, he's very good at translating certain information and adapting certain information' (ibid.). The next step was laboratory work to reconstruct the missing information step by step: 'Sometimes, we aren't able to reproduce a synthesis route described in a patent. There's what's called the "cat leap ${ }^{\prime \prime v}$. We have to study the process, to see for instance up to what point we need to heat it. Or in their patent they give a range of reaction time. We 
have to discover what the precise time is' (head of ARV projects at Far Manguinhos synthesis laboratory) ${ }^{\mathrm{xvi}}$.

In so far as the chemists of Brazilian generics producers do not have the standards of the patented molecules, which are not filed in the international pharmacopoeia, they also necessarily need to reconstruct references of these molecules in order to control the quality of their production or the active principles that they buy in the market. This is the job of the Analytical Department at the federal laboratory which serves as a reference platform for Brazilian private-sector laboratories. The reconstruction of molecule standards implies undoing and purifying the samples of the molecule that has been bought from commercial firms or from other generics producers, either Brazilian or Indian. Comparison between the samples of different providers and with the patented molecule is a particularly effective way of reconstructing these standards. The head of the Analytical Department at Far Manguinhos described this exercise to us for stavudine, for which he compared the samples of two Brazilian producers: 'And it was very interesting because when we started the analysis we noticed that one producer's contaminants were very different from another one's. I guessed that one had one synthesis route and the other one had another one. So the contaminants, the by-products of the synthesis, were different. And it was true' (head of analytical chemistry $)^{\mathrm{xvii}}$. On the basis of these results, the head of analytical chemistry at the federal laboratory negotiated with private laboratories the 
quality standards of the product that he wish to buy from them. In this interaction, the laboratories exchanged their methods for analysing the molecule: 'they sent us their method and I told them that with an analytical method like that they couldn't identify all the impurities that they produced. They told us that they had four or five by-products. We sent them a chromatogram which showed that they had 13 by-products. They agreed that our method was good and that they had to improve their process'.

Although the federal laboratory and private laboratories exchange information, local standards still differ. This means, for example, that even if one particular public laboratory accepts a raw material, another one may refuse it. In 2002 the federal laboratory received a grant from the Drug Agency, ANVISA, to produce ARV standards and to put them into the public domain $^{\text {xviii. }}$ This painstaking task, which meant reserving equipment at the Far Manguinhos synthesis department to undertake work on the purification of molecules, had the result of enhancing the quality of the laboratory's work: 'That is a new experience for people in the synthesis department, to learn to purify something to such a purity standard ${ }^{\prime \text { xix }}$. Although this work is not yet complete, the head of the laboratory is planning on compiling and making available a data base containing all these references: 'Because of this gain of knowledge about references of later substances, references of intermediates, references of impurities, we could build a databank, which would be available wherever necessary, or at least the knowledge would be here or it will be 
catalogued somewhere and we'll have samples' (ibid.). This database would in fact be the equivalent of a pharmacopoeia.

The private laboratories and Far Manguinhos have accomplished a huge task in reverse engineering the synthesis processes of the different ARVs, including second-generation ARVs under patent, which they are not authorized to produce but for which they possess the technology. All the R\&D managers whom we met described a gradual reverse engineering process to us, upstream, with a view to acquiring the complete synthesis of the molecule, even if the laboratory decided to use intermediate products bought from another producer : 'I worry first only with the last stage of the synthesis... we import $E$, then we start importing $D$, and from $D$ we make $E$... And then we go back, back and back. And this is what is called the reverse engineering, until you get to the first raw material' (R\&D director, Far Manguinhos ${ }^{\mathrm{xx}}$ ). Once this process is complete, the laboratory has all the steps of the synthesis: 'I start there, from the back, and I do all the intermediates with a load of steps - which gives me technological independence' $(\mathrm{R} \& \mathrm{D} \text { director at Nortec })^{\mathrm{xxi}}$. The scientific director at Cristalia confirmed to us the implications of complete synthesis of the molecule: 'for example for ritonavir we developed 17 synthesis steps, which is a complete synthesis. We should have the technology for the entire synthesis because we could have difficulties buying intermediates; there might turn out to be no producers of intermediates; we have to have the technology to be independent; we could also have problems obtaining certain 
${\text { intermediates from international laboratories }{ }^{\prime \times x i i}}$. A chemist at the federal laboratory, who is developing synthesis processes not to industrialize them himself but to acquire knowledge on this type of molecule and, where relevant, to transfer these processes to industry, has the same strategy: 'Even in the case that they buy the intermediate, they still go through the whole synthetic route so they have ... they gain knowledge with every synthesis ${ }^{\prime x x i i i}$.

We observed a phenomenon of learning, by laboratories which had accumulated knowledge on these different families of molecules, so that recent reverse engineering processes had not taken as long as the first ones had: 'for ritonavir, the development of the synthesis took two years; for lopinavir, six months; because lopinavir and ritonavir have partially similar structures, similar types of chemistry. It's far easier today to develop new syntheses' (R\&D director at Cristalia). Naturally these learning phenomena do not apply to different molecule categories and certain molecules prove to be particularly difficult to analyse and reproduce, such as DDI that Labogen took three years to develop, or indinavir for which Far Manguinhos had to ask for help from a private laboratory to complete its analyses.

We have seen that part of the reproduction of molecules and of their synthesis processes required invention or reinvention by chemists at the generics laboratories, in order to reconstruct the cat leap that had carefully been omitted in the patent document, or to improve the processes described in the patent when it was deemed to lack viability: 'I thus discovered that there was a synthesis 
route that they use in anti-protease patents which is a bit-I'm going to exaggerate - a bit suicidal as regards profitability. They use steps that I've always heard people in France saying are useless in industry because they're too expensive, they're too dangerous' (laboratory manager) ${ }^{\text {xxiv }}$. Generics laboratories improve synthesis paths to increase the productivity and profitability of their processes. Labogen thus developed two new synthesis routes, one for ganciclovir and the other for stavudine. It chose to keep both of these improvements secret: 'The problem is that these two products can be manufactured in other countries. If I patent, the others will know it and will make it. So we prefer to keep it a secret' (R\&D manager). For stavudine, improvement of the process laid the foundations for the laboratory's competitiveness: 'in patents, they use $4 \mathrm{~kg}$ of raw materials to produce $1 \mathrm{~kg}$ of stavudine. Here, we produce $1.9 \mathrm{~kg}$ for $1 \mathrm{~kg}$. We've crystallized this intermediate. We like this new route' (R\&D manager). Another private laboratory in Rio has also developed original technologies for lamivudine and estavudine: 'We created a lamivudine process, better than the one cited in the literature, mainly in the part in which we alter the crystalline form. We have other successes, for example on estavudine, on which we perform a different purification, based on the one that they do, but different from what they do in the patents and the literature' (R\&D director). During our visit to Nortec's R\&D laboratory in April 2006, the chemists showed us a lamivudine sample on which they were working to improve the synthesis. The process improvements were a natural outcome of 
reverse engineering. They were kept secret, so as not to give weapons to the Indian or Chinese rivals. The generics laboratories do nevertheless patent the formulation improvements that they develop. Labogen patented a formulation technique applicable to $\mathrm{ARVs}^{\mathrm{xxv}}$. The Sao Paulo laboratory also filed three patents in 2003 and 2004, on new protease inhibiting compounds and their production process ${ }^{\mathrm{xxvi}}$. These different patents clearly show the overlap between reverse engineering and invention.

3- Exchanges and cooperation between public laboratories, universities and private laboratories for reverse engineering and research on ARVs

We have seen that private generics laboratories were spin-offs from hospitals, universities and the Far Manguinhos federal laboratory. In this section we would like to show that since the mid-1990s, the reverse engineering of ARVs has relied on many technological exchanges, whether informal or contractualized, between three types of laboratory: private, public, and university. When small or medium-sized Brazilian public or private laboratories required a large knowledge base for copying ARVs, they immediately initiated interaction with Far Manguinhos or with private laboratories producing API (Cassier and Correa, 2003), or between these laboratories and the chemistry departments at universities. More recently, two private laboratories concluded 
an agreement to share the reverse engineering of the synthesis of an antiretroviral.

We witnessed informal exchange between the Analytical Department of Far Manguinhos and two Brazilian producers of API (Labogen and Microbiologica) to develop molecule testing tools and to improve the AZT synthesis process at one of the laboratories. Labogen also reverse engineered nevirapine in cooperation with the Far Manguinhos public laboratory, in the framework of a contract and on the basis of a division of work. Far Manguinhos carried out the bibliographic research and a laboratory-scale synthesis, while Labogen undertook the scale up. In addition to trading documentation, there were staff exchanges to transfer the technology: 'they came here and our technicians went over there. We did all the development of the synthesis' (managing director of the factory). This research cooperation was designed to supply the active principle to the federal laboratory which would then manufactue the final drug.

There is also long-term cooperation between the Far Manguinhos federal laboratory and the Nortec laboratory, renewed every five years since 1982. Nortec was a spin-off from the federal laboratory and cooperation between the two is on-going. In 2003 we witnessed a transfer the other way round: a Nortec chemist became deputy director of Far Manguinhos. He entered the ARV field accidentally, to help the federal laboratory to purify an ARV: 'antiretrovirals became our business when the government had a problem with a drug, with a 
raw material. We had purified it here and we found ourselves involved in antiretrovirals. We made lamivudine, zidovusine, estavudine and didanosine' $(\mathrm{R} \& \mathrm{D} \text { director })^{\mathrm{xxvii}}$. Whereas Nortec developed the synthesis processes of these molecules in-house, it used the references and quality control methods developed by the Far Manguinhos laboratory: 'For these products there's no methodology in the pharmacopoeia. For that, honestly, we were helped by Far Manguinhos. Because the Analytical Department at Far Manguinhos has the skills for that. So when they say that the method for zidovudine is this, as far as possible we follow the methods that the Far Manguinhos Analytical laboratory has recommended. The main in-house competencies are the methods for controlling the zidovudine synthesis process. That's not in Far Manguinhos' field'. The same cooperative schema was applied to develop the copying of two molecules patented in Brazil, efavirenz and nelfinavir, for which the government considered compulsory licences in 2003: 'we proposed a joint development mechanism, of both nelfinavir and efavirenz ... the exchanges mainly concerned the definition of impurity profiles. The head of analytical chemistry at Far Manguinhos had been engaged in this with our quality control group here' ( $\mathrm{R} \& \mathrm{D}$ director).

The Nortec laboratory has also set up long-term cooperation with the chemistry department at the Federal University of Rio de Janeiro, financed by public research (the CNPQ). This cooperation is sufficiently stable for us to be able to talk of a form of mixed or common laboratory: six researchers with $\mathrm{PhDs}$ 
paid by the CNPQ do development work within the chemistry department at the university, under the supervision of a professor who is a consultant for the firm: 'they are working within the university on the early stage of synthesis' (R\&D manager) ${ }^{\text {xxviii }}$. This professor submits a research report to Nortec every week, and every month a seminar is held at the factory, at which the six researchers present a progress report on their work. Nortec provides all the reagents that the university laboratory needs. In return, it benefits from expertise at the university, from public funds to finance a research team, and from structured cooperation which facilitates the transfer of results in the firm. It can also evaluate $\mathrm{PhDs}$ who work in this framework and, where relevant, decide to recruit them.

Nortec has also worked in partnership with another private laboratory, Cristalia, to share the synthesis of a patented ARV. This operation was decided after a meeting between Brazilian laboratories and the government. The two partners shared the steps in the synthesis: 'It's six steps, six chemical steps. We would do the three first steps and then they would do the last three steps' (ibid.).

The chemistry department at the Federal University of Rio has played the role of distributor of technological knowledge on ARVs all these years, for the federal laboratory at Far Manguinhos and for several private laboratories ${ }^{\text {xxix }}$. From 2003 to 2006 the university laboratory produced several theses to improve ARV synthesis processes, where relevant of patented ARVs: 'we undertook studies to synthesize the frame of ritonavir and lopinavir, here in the lab. We've had very good results' (chemistry professor). At the same time, it has been 
working on new ARV families, which have been patented jointly with the Far Manguinhos federal laboratory ${ }^{\mathrm{xxx}}$. The first development work was in 2002 in a triangular network associating the Health Ministry's laboratory, the Federal University of Rio, and a private generics laboratory responsible for producing samples for the first tests. These tests yielded nothing and Far Manguinhos lost interest in the project for a while. The university then developed a second generation of these protease inhibitors, which still have to be tested. Its chemistry laboratory combines research on new synthesis processes of known protease inhibitors, with research on the identification of new families of protease inhibitors. Here there is a second type of overlap between reverse engineering and innovation, around a family of products. Reverse engineering feeds into a knowledge base on a class of molecule that can be mobilized in a variety of research projects. In this schema, innovation is more radical when it aims to discover new pharmaceutical products.

4- Power struggles over patents and reverse engineering: the case of Efavirenz

In May 2007 the President of Brazil signed a decree on a compulsory licence for the importation and production of efavirenz, 'in the public interest and for noncommercial purposes'. This decision was the outcome of a series of power struggles over this molecule since 2001 , and was closely related to reverse 
engineering work by public and private laboratories to develop the technology and prepare to produce it: 'I think of how the whole AIDS group started: the philosophy is to be ready' (R\&D director, Far Manguinhos, December 2006). The legal tug-of-war over patents mobilized arguments on public health interests and the laboratories' reverse engineering work to acquire the technology. Note that all the generics firms that we met worked on second-generation patented ARVs from 2001 to 2007, even though they could not launch their production. They constantly accumulated technological knowledge. In such cases their research is an $R \& D$ expenditure that can be recovered only if there is a compulsory licence. On the other hand, the fact of having the technology weighed in the decision to take out a compulsory licence. Finally, the last element in this combined story of law and technology, the compulsory licence decision of May 2007, also benefited from a federal court decision in December 2006 authorizing Far Manguinhos to import the raw material for efavirenz from India so that it could conduct research for public health purposes. This meant that it could reverse engineer patented efavirenz ${ }^{\mathrm{xxxi}}$.

The first dispute concerning efavirenz appeared in 2001 when Merck sent a warning to the Far Manguinhos federal laboratory prohibiting it from procuring the raw materials to make efavirenz, from Indian suppliers. Merck did not sue the laboratory; it tried to pressurize it into giving up its reverse engineering work. Far Manguinhos replied that Brazilian patent law authorized research on imported drugs provided that it was not for commercial purposes. At the time, 
the director of Far Manguinhos used reverse engineering research as a credible threat to obtain price discounts on efavirenz which accounted for $10 \%$ of the Brazilian Aids Programme's budget. At the same time it wanted to build up enough technology to be able to produce the drug if the government opted for a compulsory licence: 'If they negotiate a lower price, we are not going to manufacture it, but if they don't, we want to be prepared' (E. Pinheiro, March 2001). Merck eventually agreed to lower its price of efavirenz and the government withdrew its threat of a compulsory license. The same negotiation process was repeated in 2003.

Between 2001 and 2007, Far Manguinhos continued its work on efavirenz. In December 2002 we interviewed the R\&D manager in charge of the ARV project. She confirmed that researchers at Far Manguinhos had developed almost the entire sequence of efavirenz; all that was lacking was the last step which had proved to be highly complicated. At the time, Far Manguinhos had three monographs on the synthesis, standard and formulation of the drug. In 2004 the federal laboratory embarked on negotiations with Merck, aimed at obtaining a voluntary licence to produce the drug itself ${ }^{\mathrm{xx} x i i}$. During the same period the LAFEPE, a public laboratory at Recife, registered a drug 'similar' to efavirenz with the Brazilian drug agency ${ }^{\text {xxiii }}$. Merck then froze negotiations on the voluntary licence. This crisis with Merck attests to the reality of the reverse engineering work undertaken by Brazilian laboratories, until registration of a similar drug by ANVISA. Far Manguinhos did nevertheless manage to revive 
the negotiations and to schedule the steps of the voluntary licence. This endeavour eventually failed, according to Far Manguinhos because Merck refused to transfer to it the technology for producing efavirenz, before the expiry of its patent in 2011 .

During the same period, in the early 2000s, private laboratories developed the synthesis technologies of efavirenz. Cristalia, Labogen and Nortec had engaged in this work at the request of the Health Ministry, to prepare for the possibility of a compulsory licence: 'last year we worked on patented products: nelfinavir and efavirenz. The government told us that it was going to break the patents. It asked us to do development. We spent a lot of money, especially purchasing raw materials. And nothing happened. We did this development up to the pilot stage: $5 \mathrm{~kg}$ for nelfinavir and $1 \mathrm{~kg}$ for efavirenz' (Labogen managing director $)^{\text {xxxiv }}$. While the managing director of Labogen emphasized the cost of reverse engineering that it would not be able to recover in the short term, the scientific director of Cristalia highlighted the advantages in terms of knowledge: 'we have the technology for lopinavir, nelfinavir, efavirenz; we have developed these technologies but we can't produce them; they're under patent ... In any case it's not a lost technology. In my opinion, it's important to work on these molecules' (Cristalia, April 2004). At the time, despite these developments in the private laboratories and the federal laboratory, government advisers were questioning Brazilian laboratories' technological capacities. They believed that 
this uncertainty explained the government's reluctance to decide on a compulsory licence ${ }^{\mathrm{xxxv}}$.

In 2004 Merck sued Far Manguinhos for its reverse engineering of efavirenz. It accused the laboratory of launching a public procurement procedure for the active principle of efavirenz while the two parties were involved in confidential negotiations on a possible voluntary licence. The firm requested the suspension of the importation of the generic equivalent of efavirenz, produced by an Indian laboratory. Initially the Rio de Janeiro federal court upheld Merck's claims and ordered a suspension on imports of the product, but on appeal it quashed this ruling, in August 2005 ${ }^{\mathrm{xxxvi}}$. The court based its new decision on Far Manguinhos' argument which emphasized the necessity to reverse engineer the molecule, and the public health interest in doing so: 'delays in the development of the above-mentioned research will delay the acquisition of the technology and the production of generic drugs'. The court stated that '... delaying or banning production will harm public health due to the lack of generic drugs on the market $^{\prime x x x v i i}$. In December 2006, when the regional federal court upheld its ruling, the managing director of Far Manguinhos encouraged the government to opt for a compulsory licence on efavirenz. The laboratory claimed that it could produce the drug at $50 \%$ of the price proposed by Merck. In May 2007 the president of Brazil signed a compulsory licence decree which stipulated that efavirenz would initially be bought from an Indian generics producer, until 
2008, after which Far Manguinhos and the Lafepe, a public laboratory in Recife, would produce $\mathrm{it}^{\mathrm{xxx} \text { iii }}$.

The compulsory licence decision was taken after eight years of researchdevelopment to reverse engineer the molecule. The fact that three Brazilian laboratories - a public laboratory, Lafepe, and two private laboratories, Cristalia and Cellofarm - obtained from ANVISA in 2003 and 2004 the registration of drugs containing efavirenz, that they had developed, clearly shows this process of acquisition of the technology. The legality of the purchase of generic raw materials for the reverse engineering was itself the subject of a court case. Authorization to practice reverse engineering of the patented molecule was justified by the necessity to avoid delays in acquiring the technology and production of generic drugs, in order to safeguard the public interest and public order. Technological learning was thus justified by the protection of public health and the urgency associated with it: 'A single day's delay in developing the above-mentioned research due to a lack of the pharmaceutical raw materials required, will entail delays in obtaining the expected result for acquiring the technology and producing generic drugs'. To reinforce this argument, the court ruling referred to the law on generics passed in 1999 to facilitate patients' access to treatment ${ }^{\mathrm{xxxix}}$.

\section{Conclusion}


Our interviews with chemists at Brazilian generics laboratories informed us on a particular mode of reproduction of technology and know-how, which

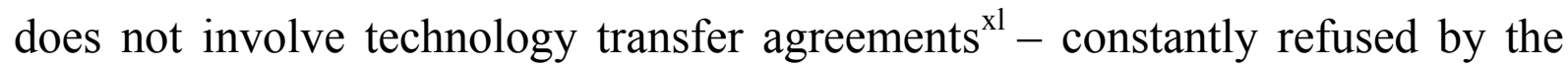
laboratories that owned pharmaceutical patents - or voluntary trading of knowhow between researchers or engineers ${ }^{x l i}$. The reproduction of knowledge and techniques takes place here through imitation and partial reinvention of the original technology. Our findings are consistent with the conclusions of economists Paula Samuelson and Suzanne Scotchmer: 'Reverse engineering may be a slower and more expensive way for information to percolate through a technical community than patenting or publication, but it is nonetheless an effective source of information ${ }^{\text {'lii }}$. It requires skilled if not experienced chemical engineers recruited from university, the Brazilian chemicals and pharmaceuticals industries, or from laboratories that control the quality of sanitary products. This learning by copying process has benefited from the technological heritage of companies specialized in reverse engineering, especially Codetec in the Brazilian chemicals and pharmaceuticals field. The reverse engineering of ARVs in Brazil has also taken place in the framework of partnerships and cooperation between private, public, and university laboratories, sometimes under long-term R\&D and technology transfer agreements such as the one between Nortec and the Federal University of Rio de Janeiro chemistry department. The acquisition of these technologies facilitates the development of local production capacities ${ }^{x l i i i}$, including innovation 
capacities in the pharmaceuticals field, as evidenced by the first patent applications filed since 2001 by the generics laboratories studied. Initiatives have been taken to strengthen innovation policies in which universities and industries cooperate ${ }^{\text {xliv }}$, and to stabilize partnerships between public and private laboratories for the provision of raw material that meets satisfactory quality standards ${ }^{\mathrm{xlv}}$.

This process of acquiring industrial knowledge via reverse engineering led to court action when it concerned drugs patented under Brazil's new patent law of 1996. Merck sued the Far Manguinhos federal laboratory for importing raw material from an Indian generics producer - raw material that was used for research purposes, with a view to acquiring the production technology of this ARV and obtaining its registration as a generic drug by the Brazilian drug agency. The October 2005 and December 2006 rulings by the Rio de Janeiro federal court recognized and authorized the practice of reverse engineering of patented molecules. The Far Manguinhos Institute was authorized 'to immediately purchase the drugs necessary for the regular development of Fiocruz's research activity'. Two categories justified the immediate engagement in reverse engineering of the patented molecule: 'public order' and 'public health'. This court decision paved the way for the compulsory licence on efavirenz when this molecule was associated with these two legal categories. The compulsory licence decree of May 2007 specified the terms 'public interest' and 'public and non-commercial use'. This ruling by the Rio de Janeiro federal 
court embedded the reverse engineering of drugs in Brazilian health policy. It participated in what can be called a 'biopolitics' of drugs, in the sense of Michel Foucault, that is, the application of policies designed essentially to protect populations and their health ${ }^{\mathrm{xlvi}}$.

\footnotetext{
${ }^{\mathrm{i}}$ Interviews with the logistics director at Far Manguinhos and with the scientific director at Nortec, both in April 2006.

ii 'Post-Trips Options for Access to Patented Medicines in Developing Countries', F. Scherer and Watal, Commission on Macroeconomics and Health, January 2001.

iii See, for example, our presentation in March 2006 at the Far Manguinhos Institute : "The relationships between public research and industry : creation of technology and intellectual Property management”.
}

iv The CEME was founded in 1971. Its mission was to stimulate national research laboratories to produce raw materials for drugs. Twice, in 1974 and in 1980, there were plans to transform the CEME into a public drug manufacturing firm (Luchesi 1991 ; Bermudez, 2001).

${ }^{\mathrm{v}}$ The Nortec laboratory was founded in 1982 with a cooperation agreement between the Oswaldo Cruz Foundation and the private firm Norquisa. This agreement has been renewed every five years since then. Initially Nortec's R\&D work was carried out at the FarManguinhos Institute itself. Nortec chemists came from Fiocruz, the Federal University of Rio de Janeiro (UFRJ) - in particular Professor Alberto Mansur, the first director of the new firm -, the Military Institute of Engineering (IME), the Catholic University of Rio (PUC), and the State University of Rio de Janeiro (UERJ) (interviews with the Nortec R\&D manager, May 2004, April 2006, and communication in December 2007).

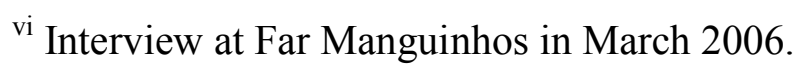


vii Interview in April 2003 at Microbiologica.

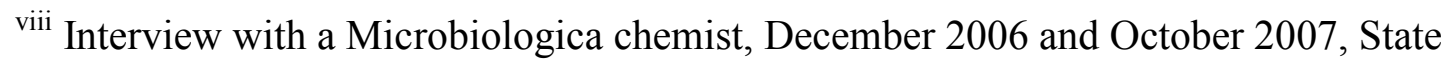

University of Rio de Janeiro.

${ }^{\text {ix }}$ Interview in April 2004 at Labogen.

${ }^{\mathrm{x}}$ Interview in April 2006 at Nortec.

${ }^{x i}$ The Oswaldo Cruz Foundation is a leading scientific institution in the life sciences and an industrial institution producing vaccines (Bio Manguinhos) and drugs (Far Manguinhos). It was founded in 1900 along the same lines as the Pasteur Institute, created to produce serums and vaccines against the plague.

xii Interview in April 2006.

${ }^{\text {xiii }}$ Interview at Microbiologica in April 2003.

${ }^{\text {xiv }}$ Interview at Labogen in April 2004.

${ }^{\mathrm{xv}}$ The 'cat leap' metaphor is as follows: the cat taught the tiger to leap and when the tiger thought that he had learned everything he leapt at the cat to eat it. But the cat side-stepped the tiger, something that he had been careful not to teach him, and was thus able to escape from his ungrateful pupil.

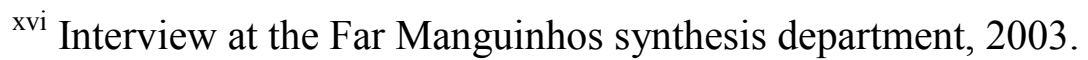

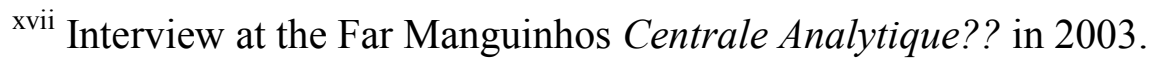

${ }^{\text {xviii }}$ Cf. our interviews at the synthesis department in December 2002, analysed in Cassier and Correa, 2003.

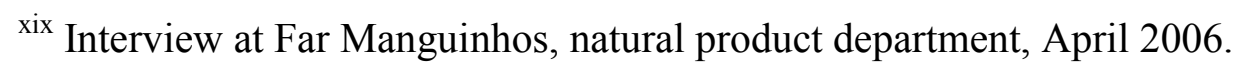

${ }^{\mathrm{xx}}$ Interview at Far Mangunhos, December 2002.

${ }^{x x i}$ Interview in May 2004 at Nortec.

xxii Interview at Cristalia in April 2004.

xxiii Synthesis department at Far Manguinhos, December 2006. 
${ }^{\text {xxiv }}$ Interview in December 2002 at Far Manguinhos with a chemist responsible for bibliographic studies on ARV patents.

xxv 'Ready for use injectable solution, mainly for treating immunodepressed patients carrying viral infections', WO2004BR00235; EP200407971152; BR305339 2003.

xxvixxvi 'Pharmaceutical composition with increased bioavailability suitable for the administration of oral protease inhibitors', WO2005007069 ; 'Pharmaceutical composition, process to prepare said composition, use of the respective composition in the treatment of immunodeficiency caused by HIV infection', W02006086865 ; 'Soluble stable pharmaceutical composition for the administration of protease inhibitors', WOO3105826. May 2005.

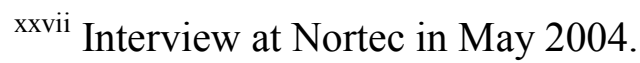

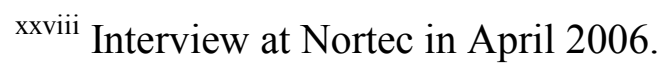

${ }^{\text {xxix }}$ We held two interviews and made two visits to the Octavio Antunes university laboratory in Rio de Janeiro in March 2003 and December 2006.

${ }^{\mathrm{xxx}}$ Proteases inhibitors and their pharmaceutical uses, WO0242412. 2001.

${ }^{x x x i}$ This ruling by the Rio de Janeiro federal court in December 2006 is consistent with another exemption in case history. In the Bolar case the court authorized the reverse engineering of patented drugs before expiry of the patent for two purposes: experimental use, and to file an application for registration with a view to putting generic drugs on the market, once the patent has fallen into the public domain (A.B. Engelberg, 1999). In Brazil the May 2007 compulsory license suspended the patent holder's exclusive right and authorized the production of generics for non-commercial use.

xxxii Interview with the director of Far Manguinhos, N. Boechat, in April 2004.

xxxiii ANVISA Resolution $\mathrm{n}^{\circ}$ 77, of 9 March 2004, published in the government gazette dated 11 March 2004. In 2003 two Brazilian private laboratories had also registered, with ANVISA, efavirenz that they had produced: Cristalia, on 11 April, and Cellofarm, on 24 April. 
${ }^{\text {xxiv }}$ Interview, April 2004 at the factory.

${ }^{\mathrm{xxxv}}$ Interview with the former head of intellectual property at Far Manguinhos, a consultant in Rio de Janeiro, March 2003. In 2004, scenarios envisaged at the Health Ministry for the production of efavirenz by local laboratories clearly indicated the three private laboratories cited above: Cristalia, Nortec and Labogen.

${ }^{\text {xxxvi }}$ Court ruling of 17 August 2005, Rio de Janeiro Regional Federal Court.

${ }^{x x x v i i}$ Court ruling of 6 October 2005, Regional Federal Court of the $2^{\text {nd }}$ Region.

xxxviii The Lafepe had already registered a formulation of efavirenz at the Brazilian drug agency, ANVISA.

${ }^{\text {xxxix }}$ Court ruling of 6 October 2005, op. cit. .

${ }^{\mathrm{xl}}$ Technology transfer agreements in the pharmaceuticals domain have been studied for example by Bertin and Wyatt, "Le Contrôle de la technologie mondiale" (1986) and, with respect to the Indian pharmaceuticals industry, by Sahu, "Technology Transfer, Dependence, and Self-Reliant Development in the Third World" (1998).

xli See, for example, the work of E. Von Hippel, 1987.

xlii The Law and Economics of Reverse Engineering, University of Berkeley, 2001.

xliii Our findings, obtained by the methods of the sociology of science, are consistent with the conclusions of the study by two chemists, undertaken in 2006 for Médecins Sans Frontières (Doctors Without Borders) and the organization ABIA (Antunes and Fortunak, 2006).

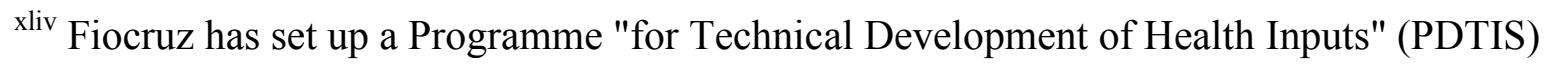
for the development of new health products (drugs, vaccines, diagnostic kits). ${ }^{x l v}$ In 2002 Elona Pinheiro tried a partnership of this type between Far Manguinhos and Cristalia. Cf. our interview with the scientific director of Nortec in April 2006, in which we were told of reflection under way on the subject. 
${ }^{\text {xlvi }}$ Michel Foucault, 1979, "Naissance de la biopolitique" in Dits et écrits, Vol. 3, 1976-1979 (English: 1997, "The Birth of biopolitics" in Ethics: Subjectivity and Truth, edited by Paul Rabinow, The New Press, New York).

\section{References}

Antunes O, Fortunak JM, 2006, "Arv Production in Brazil: an Evaluation", Report for the Brazilian Interdisciplinary Aids Association (ABIA) and MSF Brazil, 8 pages.

Bermudez J, 2001, “Au Brésil le triomphe des génériques”, Biofutur, 210, avril, 40-42.

Bertin G, Wyatt S, 1986, Multinationales et propriété intellectuelle. Le contrôle de la technologie mondiale, PUF, Paris.

Cassier M, Correa M, 2003 «Patents, innovation and Public Health : Brazilian PublicSector Laboratories' Experience in Copying AIDS Drugs »in Economics of Aids Aid and Access in Developing countries, ANRS, 89-107

Cassier M, 2006, "Relationships between the Public Research Sector and Industry : creation of technology and Intellectual Property Management”, Institut FarManguinhos, Fondation Oswaldo Cruz, 27 mars.

Engelberg A.B, 1999, "Special Patent Provisions for Pharmaceuticals : have they outlived their usefulness ?", IDEA, the Journal Of Law and Technology, 39, p 389-425. 
Foucault M, 1979, "Naissance de la biopolitique", Dits et écrits, Vol. 3, 1976-1979, Gallimard.

Foucault M, 2004, Naissance de la biopolitique, Cours au collège de France (1978-1979), Seuil.

Lucchesi G., 1991, Dependência e autonomia no setor farmacêutico: um estudo da Ceme. Dissertação de Mestrado, Rio de Janeiro: Escola Nacional de Saúde Pública/Fundação Oswaldo Cruz, 1991.

Orsi F, Hasenclaver L, Fialho B, Tigre P, Coriat B, 2003, « Intellectual Property Rights, Anti-Aids Policy and Generic Drugs », in Economics of Aid and Access in Developing countries, ANRS, 109-133.

Sahu S, 1998, Technology Transfer, Dependence, and Self-Reliant Development in the Third World, Praeger, London, 250 pages.

Samuelson P and Scotchmer S, 2001, The Law and Economics of Reverse Engineering, University of California at Berkeley, 78 pages.

Scherer F and Watal J, 2001, "Post Trips Options for Access To Patented Medicines in Developing Countries", Commission on Macroeconomics and Health, WHO, 2001, 77 pages.

Von Hippel E, 1987, “Cooperation between rivals : informal know how trading”, Research Policy, 16, 291-302. 